\title{
HISTOLOGICAL COMPARISON OF THE ALAR NASAL CARTILAGES IN UNILATERAL CLEFT LIP
}

\author{
Miguel Modolin, Glaucia Zeferino Baracat, Luiz Kamakura, Wilson Cintra Jr., \\ Luiz Gustavo Balaguer Cruz and Marcos Castro Ferreira
}

RHCFAP/3086

MODOLIN M et al. - Histological comparison of the alar nasal cartilages in unilateral cleft lip. Rev. Hosp. Clín. Fac. Med. S. Paulo 57(4):143-146, 2002.

Patients with unilateral cleft lip display characteristic nasal changes that are independent of the degree of deformity. Defenders of the intrinsic theory consider these deformities to be due to embryogenic alterations of the alar nasal cartilages. Those that propose the extrinsic theory defend the thesis that the deformity is due to disorganization of the perioral muscles deformed by the cleft. The purpose of this study is to contribute histological evidence to help clarify the issue.

PATIENTS AND METHODS: Specimens of the lateral portion of both the healthy and the cleft side of the alar cartilages were obtained from 18 patients. These uniformly cut specimens were stained by hematoxylin and eosin. Samples from 2 patients were excluded due to imperfections. The same pathologist examined all the slides. He was unaware of the origins of the specimens; he counted the number of chondrocytes and quantified the cartilage matrixes.

RESULTS: All data was analyzed statistically, and no significant statistical differences were apparent, either in the number of chondrocytes or the cartilage matrix between the healthy side and the cleft side.

DISCUSSION: These results apparently support the group that defend the extrinsic theory; nevertheless, the doubt about the composition of the cartilage matrix remains, not only concerning the glycosaminoglycans that compose them, but also regarding elastin and collagen and its linkages that can cause different degrees of collagen consistency.

DESCRIPTORS: Cleft lip nose. Alar cartilages. Histological study.

In addition to the lip deformity, unilateral cleft lips also display a nasal change characterized by flattening of the nasal wing. The latter is deviated outward, downward, and behind on the side of the cleft ${ }^{1}$. Together with this deformity, deviations of the nasal septum, columella, tip, and nasal pyramid are possible.

The alar nasal change is always present independently of the extent of the cleft. Clefts range from the most simple defects, characterized by a simple dent in the vermilion border, to the most complex forms that involve the entire lip and nasal floor ${ }^{1,2}$.

Several theories have been presented to attempt to explain the de- formity, and these theories can be categorized as intrinsic or extrinsic. Those in the former group proclaim that cleft palette results from a structural deficiency of the alar cartilage ${ }^{3,4,9}$. The extrinsic theories proclaim that cleft palette occurs because of the disordered action of the deformed perioral muscles on the nasal wing ${ }^{3,5-7}$.

Regarding the numerous discussions for or against this or that theory, there are puzzling doubts remaining that motivate new research. The subject has resurfaced, and the objective

From the Division of Plastic Surgery, Hospital das Clínicas, Faculty of Medicine, University of São Paulo. of this report is to study the number of chondrocytes and to quantify the cartilage matrix on the normal side as well as the fissured one to identify whether or not there are differences that may support any theory.

\section{PATIENTS AND METHOD}

Eighteen patients ranging in age from 1 to 6 years (mean 2.9 years) comprised the study. Ten were females and 8 were males, including 8 Negroes, 6 Caucasians, and 4 Orientals. Twelve patients displayed labiopalatine clefts, with 9 on the left side and 3 on the right. The cleft was on the left and in- 
complete in 6 cases, i.e., with only lip involvement. All patients possessed the nasal characteristic of the pathology; at closure of the lip cleft (cheiloplasty), a rhinoplasty was also performed.

Using a $2 \mathrm{~mm}$ perforator, intranasal samples of the lateral segments of the nasal wings were obtained from the 18 patients on both the normal and the cleft sides. These 36 specimens included mucosa and cartilage. All were cut with the same micrometer, stained with hematoxylin-eosin, and examined by the same pathologist who was unaware of the origin of the tissues. He was asked to do a histological examination, that is, to count the chondrocytes and assess the cartilage matrix. Of the 36 samples, those from 2 patients were excluded because the histological preparations were imperfect and could jeopardize the results.

Initially, the number of chondrocytes in 10 randomly chosen fields on each slide were counted at 400 magnification. The number of cells in each field was added, and an average was obtained (Table 1).

Then the histological specimens were also analyzed (at 400X) through

Table 1 - Average number of chondrocytes in 10 randomly examined fields.

\begin{tabular}{ccc}
\hline Patients & $\begin{array}{c}\text { Healthy Side } \\
\text { No. of Cells } \\
\text { (means / } \\
\text { 10 fields) }\end{array}$ & $\begin{array}{c}\text { Cleft Side } \\
\text { No. of Cells } \\
\text { (means / } \\
10 \text { fields) }\end{array}$ \\
\hline 1 & 64 & 84 \\
2 & 84 & 68 \\
3 & 64 & 51 \\
4 & 63 & 61 \\
5 & 56 & 85 \\
6 & 60 & 49 \\
7 & 88 & 96 \\
8 & 72 & 75 \\
9 & 45 & 73 \\
10 & 75 & 105 \\
11 & 75 & 109 \\
12 & 62 & 63 \\
13 & 74 & 40 \\
14 & 73 & 85 \\
15 & 48 & 35 \\
16 & 33 & 81 \\
\hline
\end{tabular}

a square reticulum with an area of 62,500 micrometers square containing 100 points. The points on the chondrocytes and on the cartilage matrix were counted in 10 fields, resulting in the recording of 1000 points per slide. The relationship between the area occupied by chondrocytes and the cartilage matrix was calculated by dividing the number of points in chondrocytes by those in the matrix. Therefore, for each 1000 points analyzed, $X$ is the number of cells and $1000-\mathrm{X}$ is the amount of cartilage matrix, in accordance with Weibel's ${ }^{10}$ morphological model (Table 2).

\section{RESULTS}

All the data underwent statistical analyses. Hence, the paired $t$ test was utilized to analyze the variations in the numbers of chondrocytes of both the normal side and the cleft side. The chi square test was employed for the cartilage matrix.

These statistical analyses permitted us to conclude that there were no significant quantitative differences either in the normal or the cleft side regarding the number of chondrocytes or the cartilage matrix.

\section{DISCUSSION}

During embryonic development, mesenchymal cells with a large capacity for proliferation and differentiation form a major part of the nasofrontal process. In this way, the cartilaginous skeleton of the future nose and especially the alar cartilages develop, forming the framework of the nasal wings. The hyaline cartilage tissue, which is derived from the mesenchyme, contains a cellular component, the chondrocytes, and an abundance of intercellular material that is the cartilage matrix composed of a unit of mucopolysaccharide acids generically termed glycosaminoglycans, collagen, and elastin.

The proponents of the intrinsic theory state that during embryogenesis, alterations occur in cells originating from the neural crest. The alterations are accompanied by disorderly migration, differentiation, and proliferation resulting in mesenchymal impairment of the nasofrontal process and appearance of the cleft and nasal deformity, along with resulting changes in the cellularity and matrix of the alar cartilages. Stark \& Kaplan $(1973)^{4}$ and Avery (1976) ${ }^{3}$ eloquently promoted this hypothesis. Stark \& Kaplan ${ }^{4}$ as-

Table 2 - Cartilaginous material in 10 fields randomly examined in accordance with Weibel's morphological model.

\begin{tabular}{ccccc}
\hline & \multicolumn{2}{c}{ Healthy Side } & \multicolumn{2}{c}{ Cleft Side } \\
Patients & Chondrocytes & Matrix & Chondrocytes & Matrix \\
\hline 1 & 287 & 713 & 368 & 632 \\
2 & 307 & 693 & 299 & 701 \\
3 & 449 & 551 & 445 & 555 \\
4 & 270 & 730 & 296 & 704 \\
5 & 284 & 716 & 255 & 745 \\
6 & 452 & 548 & 431 & 549 \\
7 & 304 & 696 & 354 & 646 \\
8 & 431 & 569 & 373 & 627 \\
9 & 310 & 690 & 321 & 679 \\
10 & 246 & 754 & 281 & 719 \\
11 & 374 & 626 & 286 & 714 \\
12 & 309 & 691 & 231 & 769 \\
13 & 440 & 560 & 124 & 876 \\
14 & 253 & 747 & 372 & 628 \\
15 & 256 & 744 & 272 & 728 \\
16 & 339 & 661 & 223 & 777 \\
\hline
\end{tabular}


sessed the ectoderm of 3 embryos with clefts, and according to their established parameters, defective embryogenic lamina would give rise to the clefts with consequent nasal deformity. Avery affirmed that the defect in the capsule of the nasal cartilages found in 5 embryos with clefts could explain a disorder of the chondrogenic potential and consequent deformity of the alar cartilage ${ }^{3}$. Prior to this study, Patten $^{9}$ (1971) formulated the hypothesis that there could be mesodermal hypoplasia with resulting reduction in capacity of cartilage formation.

Huffman and Lierle (1949) ${ }^{1}$, Stenstrom and Oberg $(1961)^{8}$, Novoselov (1979) $)^{5}$, and BeyoungYum $(1998)^{9}$ postulated that the nasal deformity is due to extrinsic factors. Specifically, these are the forces exerted by the perioral muscle whose disorganized dynamics caused by the cleft, acting on the nasal wing, contribute to the appearance of the cleft. In 1988, Sadove ${ }^{6}$, in a thorough comparative analysis of the alar cartilages of both the normal side and the cleft side, verified that there was no difference between them and concluded that the deformity was due to extrinsic factors. He compared his findings with those of the proponents of the intrinsic theory and found that their conclusions were based on subjective standards that required further proof.

The data obtained and analyzed in the present study enable us to conclude that there are no morphometric differences between the alar cartilages of the healthy side and the cleft side. Comparing these results with the relevant studies reported in the literature, it is valid to assume that the nasal deformity is due to the action of extrinsic forces, from the time of embryogenesis, on the nasal wing on the side of the cleft. It is reasonable to state, therefore, that the muscles on the cleft side have a dyskinetic mechanism whose resulting disordered, fragmentary, or incomplete forces exercise a deforming effect on the nasal wing and consequently on the alar cartilage.

Nevertheless, a thorough study is needed, especially to assess the com- position of the cartilage matrix, not only of the combinations of glycosaminoglycans, but also of collagen and its colligations that can cause different degrees of collagen consistency, which can vary its shape. The supposition of the presence of collagen with different degrees of consistency permits us to formulate a third hypothesis that links the intrinsic and extrinsic theories, i.e., that alar cartilage of a different consistency would be more susceptible to dyskinesia of the perioral muscles deformed by the presence of the cleft.

\section{ACKNOWLEDGEMENT}

The authors wish to thank the following physicians: Drs. Diogenes Laercio Rocha and Silvio Sterman for their help in obtaining records for this study, Dr. Marcelo Abrantes Gionnotti for analysis of histological preparations and Prof. Ruy Geraldo Bevilacqua for the statistical analysis.
MODOLIN M e col. - Estudo histológico comparativo das cartilagens alares nasais em pacientes com fissura labial unilateral. Rev. Hosp. Clín. Fac. Med. S. Paulo 57(4): 143-146, 2002.

Portadores de fissura labial unilateral, independentemente do grau da deformidade, apresentam uma alteração nasal característica. Alguns autores julgam que esta deformidade devese a alterações embriogenicas das cartilagens alares nasais, são os defensores da teoria intrínseca. Outros, que propõem a teoria extrínseca, defendem a tese de que a deformidade deve-se a ação desordenada da musculatura perioral deformada pela fissura.
PACIENTES E MÉTODOS: Em uma tentativa de trazer alguma contribuição, neste trabalho obtiveram-se amostras da porção lateral das cartilagens alares - tanto do lado são quanto do lado fissurado - de 18 pacientes. Estas amostras cortadas, uniformemente, pelo mesmo micrômetro foram coradas pela hematoxilina-eosina, no entanto, as amostras de dois pacientes tiveram que ser desprezadas dada a imperfeições. Todos os cortes foram examinados pelo mesmo patologista que, ignorando as origens, contou o número de condrócitos e quantificou as matrizes cartilaginosas.

RESULTADOS: Todos os dados obtidos foram submetidos a testes estatísticos que revelaram não haver qualquer diferença significativa, tanto quanto ao número de condrócitos quanto às matrizes cartilaginosas, entre os lados são e o fissurado.

DISCUSSÃO: Tais resultados, aparentemente, apoiam aqueles que defendem a teoria extrínseca; todavia, permanece a dúvida quanto à composição das matrizes cartilaginosas, não só dos glicosaminoglicanos que as compõem como, também, quanto à elastina e ao colágeno e suas coligações que podem determinar diferentes graus de consciência à cartilagem.

DESCRITORES: Nariz de fissurado. Cartilagens alares. Estudo histológico. 


\section{REFERENCES}

1. HUFFMAN WC \& LIERLE DM - Studies of the pathologic anatomy of the unilateral hare-lip nose. Plast Reconstr Surg 1949, $4: 225$.

2. MODOLIN M - Fissuras lábio palatinais. In: RAIA AA \& ZERBIBI EJ - Clínica cirúrgica "Alípio Correia Neto". $4^{\circ}$ ed., São Paulo, Savier, 1988. v. 1, p. 261.

3. AVERY JK - The unilateral deformity. In: MILLARD RD - Cleft craft: the evolution of the surgery. Boston. Little, 1976. p.9.

4. STARK RB \& KAPLAN JM - Development of the cleft lip nose. Plast Reconstr Surg 1973, 28:413.

5. PATTEN BM - Embryology of the palate and maxillofacial region. In: GRABB WG, ROSENSTEIN SW \& BZOCH KR - Cleft lip and palate. Boston, Little, 1971.
6. NOVOSELOV RD - Mechanism of deformities of the middle part of the face occurring by inborn unilateral cleft. Acta Chir Plast. 1979, 21:7.

7. SADOVE R, LADAGA L \& MAGEE WP - Cartilaginous histology of the cleft lip nose: providing the extrinsic etiology. Plast Reconstr Surg 1988, 81(5): 655.

8. STENSTRÖM SJ \& OBERG TRH - The nasal deformity in unilateral cleft lip. Plast Reconstr Surg 1961, 28:295.

9. BEYOUNG-YUN P, DAÍ-HYUN L \& YOUNG-HOO L - A comparative study of the lateral crus of alar cartilage in unilateral cleft lip nasal deformity. Plast Reconstr Surg 1998, 101:4.

10.WEIBEL ER - Practical methods for biological morphometry. Stereological methods. London, Academic Press, 1979. v.1 p.257.

Received for publication on October 05, 2001. 